\title{
Qualitative and Quantitative Characterization of Snake Gourd (Trichosanthes anguina L.) Mutant Lines
}

\author{
Santanu Layek ${ }^{1 *}$, M.K. Pandit ${ }^{1}$, Sanket Kumar ${ }^{1}$, \\ Arindam Das ${ }^{2}$ and Anamika Upadhyay ${ }^{1}$ \\ ${ }^{1}$ Department of Vegetable Science, Faculty of Horticulture, Bidhan Chandra Krishi \\ Viswavidyalaya, Mohanpur, Nadia-741252, West Bengal, India \\ ${ }^{2}$ Division of Vegetable Crops, Indian Institute of Horticultural Research, Bengaluru - 560089, \\ Karnataka, India \\ *Corresponding author
}

\section{A B S T R A C T}

\section{Keywords}

Mutants,

Qualitative, Yield,

Fruit shape, Snake gourd

Article Info

Accepted:

15 July 2019

Available Online:

10 August 2019
Advanced mutant lines have been selected from $\mathbf{M}_{4}$ generation and its qualitative and quantitative characters were evaluated in spring-summer season at Bidhan Chandra Krishi Viswavidyalaya, West Bengal, during 2016. Different qualitative characters of mutant lines have been recorded and observed that the some characters changed from that of the parental control. Analysis of variance due to treatments was significant for all the characters proved higher variability among the mutant lines. Reduced number of primary branches and number of nodes on the main stem were observed in all the studied mutant lines against control. Among the mutant lines, earliest flowering, maximum fruit length and girth were observed in BCSG-2. BCSG-4 registered minimum sex ratio, average fruit weight, fruit girth and fruit length, whereas maximum number of fruits per plant and fruit yield per plant were recorded than the other putative mutants. Though, no putative mutants surpassed the parental genotype (GB Desi) for fruit yield per plant. A mutant, BCSG-4 found to be the best for fruit yield, number of fruits, sex ratio and fruit shape. Hence, the stability of the desirable changes should be checked in successive generations.

\section{Introduction}

Snake gourd (Trichosanthes anguina L., Cucurbitaceae, $2 \mathrm{n}=2 \mathrm{x}=22$ ) is an annual, hardy, monoecious and day neutral herbaceous climbing type vegetable, which is commonly consumed by most of the Indian peoples (Chakrabarti, 1982).

It possesses high medicinal and nutritional value as equipped with ample source of minerals, fibre and other nutrients to make the food wholesome and healthy (Ahmed et al., 2000).

An envisaged genetically diverse selection of suitable crop varieties are neither available to farmers nor the current breeding strategies assure for delivering them (Tester and Langridge, 2010). The genetic variability is highly advantageous for developing new cultivars, which may be chance through 
spontaneous changes and induced mutagenic treatments. In order to increase the incorporation of traits from non-adapted genetic resources (landraces and wild relatives) in improvement of cucurbits, parental materials can also be induced to mutate as means for unleashing new alleles of genes that control the traits (Mba et al., 2012). By using mutant plants, function of many important genes that regulate different developmental processes or agronomic traits, has been identified (Wu et al., 2015).

Gamma rays are commonly used in haploidy programmes because of their simple application, good penetration, reproducibility, high mutation frequency and less disposal problems (Chahal and Gosal, 2002). Plant characters such as height, disease resistance, yields and nutritional qualities have been obtained through induction by mutagenic agents such as gamma ray (Iwo et al., 2013). Effective and a wide range of induced variability were observed in snake gourd mutant lines for short fruit, higher fruit diameter and reduced vine length (Sidhya and Pandit, 2015). Considering the aforesaid facts, the present experiment was carried out for characterization of four putative mutants along with the parental line, GB Desi for different qualitative and quantitative characters in the $\mathrm{M}_{4}$ generation.

\section{Materials and Methods}

The present investigation was carried out at the Horticulture research station, Mondouri, Bidhan Chandra Krishi Viswavidyalaya, Nadia, West Bengal, during February to July of 2016. The experimental materials for the present study comprised of four elite mutant lines of snake gourd (BCSG-1, BCSG-2, BCSG-3 and BCSG-4) derived from gamma ray radiated $G B$ Desi seeds $\left(\mathrm{M}_{4}\right)$ and a parental control (GB Desi without treatment), which were collected from Department of
Vegetable Science, Bidhan Chandra Krishi Viswavidyalaya, Mohanpur, Nadia, West Bengal. Five random plants per replication were selected to record the data on different characters for each genotype in $\mathrm{M}_{4}$ generation. The recorded data were averaged to get mean values. Analysis of variance for randomized block design was carried out according to the procedure suggested by Gomez and Gomez (1983). The genotypic and phenotypic coefficients of variation were estimated as per Burton (1952). Heritability in broad sense was computed according to Allard (1960). Genetic advance and genetic advance as per cent of mean was calculated using the method of Johnson et al., (1955).

\section{Results and Discussion}

Different qualitative characters of mutant lines have been recorded and compared with the parental control (Table 1). There are some characters observed in the $\mathrm{M}_{4}$ generation of four mutant lines, which remain unchanged over the control viz., growth habit (viny), stem shape (angular), petiole pubescent (presence of pubescence), lamina colour (light green), tendrils type (coiled \& branched), flower colour (white) and fruit surface (smooth and striped).

Several macro-mutations were observed in many of the qualitative characters. Pubescent with green stem was observed in all the mutants except control that have pubescent dark green stem. Lamina was entire in control, serrated type in BCSG-2, serrated with multifid type in BCSG-3 and BCSG-4. Light green fruit rind colour was found in BCSG-1 and BCSG-3, while darkish light green fruit rind colour was observed in BCSG-2 and BCSG-4. Fruit shape i.e., short and clubshaped (BCSG-4) to elongated (BCSG-1 and BCSG-2) or medium shaped, which suggest that gamma radiation could create phenotypic variability in snake gourd lines. 
Analysis of variance due to treatments was significant for all the characters suggesting that there is variability in the materials under study (Table 2). The estimates of genotypic coefficient of variation was the highest for number of primary branches (61.64), followed by average fruit weight (40.12) and number of fruits per plant (34.89) whereas the lowest GCV was found for days to $50 \%$ flowering (6.90) followed by sex ratio (8.13) and fruit yield per plant (23.45) (Table 3).

The highest phenotypic coefficient of variation was recorded for number of primary branches (62.20), followed by average fruit weight (40.82) and number of fruits per plant (35.41), whereas the lowest PCV was recorded for days to $50 \%$ flowering (9.52), sex ratio (11.52) and fruit yield per plant (26.57).

The values of PCV were higher than GCV obtained for all the traits (Table 3). High PCV and GCV coupled with moderate to high broad sense heritability and genetic advance as per cent of mean indicated that selection based on these traits would be a rewarding one.

Improvement of a character can be accomplished only through high heritability. Broad sense heritability refers determination of the proportion of total genetic variation to total phenotypic variance. The highest heritability and genetic advance as percentage of mean were recorded in number of primary branches (98.22 and 125.85\%), number of fruits per plant (97.08 and $70.81 \%)$ and average fruit weight (96.62 and $81.25 \%$ ). However, the lowest heritability was recorded in sex ratio $(49.85 \%)$ with an expected genetic advance over per cent of mean of $11.83 \%$ (Table 3).

It seems that sex ratio is a varietal character and strongly controlled genetically but simultaneously is immensely influenced by environment. Most of the characters expressed high heritability estimates with closer PCV GCV values indicating that they may be less affected by environmental conditions.

For comparing the mean values of $\mathrm{M}_{4}$ generation mutant lines, the performance of the parental control (GB Desi), along with the mutant lines have been presented in Table 4 . Among the mutant lines, the number of primary branches ranged from 1.20 (BCSG-3) to 2.70 (BCSG-1). The reduced mean value for number of primary branches was observed in $\mathrm{M}_{4}$ generation as compared to control (5.80).

Days to $50 \%$ flowering varied from 55.80 to 68.48 with a grand mean value of 61.52 (Table $3)$. None of the mutant lines showed better performance over the control (55.80) with respect to days to $50 \%$ flowering (Table 4). Among the mutant lines, the minimum number of days taken to $50 \%$ flowering have been observed in BCSG-2 (60.20 days) followed by BCSG 4 (60.50 days) and BCSG3 (62.60 days). Dalve et al., (2009) also observed delay in flowering in okra with gamma radiation. However, Datta (1994) reported decreased flowering time in $\mathrm{M}_{4}$ generation than parental line in snake gourd. Radiation causes delay in flowering and late maturation as it inhibits gross chromosomal changes and DNA synthesis (Mikaelsen, 1968). Among the mutant lines, sex ratio ranged from 21.98 (BCSG-1) to 26.56 (BCSG-2). BCSG-2 (26.56) and BCSG-4 (25.2) recorded more number of female flowers than the control (22.40). Nath and Madan (1986) got enhanced femaleness in cucumber after irradiation with gamma ray. The range for number of nodes on the main stem was 28.50 to 53.20 with a mean value of 38.25. All the four mutant lines recorded lesser number of nodes on the main stem than the control (53.20). BCSG-1 (41.93) had significant difference with BCSG-4 (28.50) and BCSG-2 (31.80) (Table 4). 
Table.1 Qualitative characters observed in the $\mathrm{M}_{4}$ generation of four mutant lines along with control (GB Desi)

\begin{tabular}{|c|c|c|c|c|c|}
\hline Characters & GB Desi (control) & BCSG-1 & BCSG-2 & BCSG-3 & BCSG-4 \\
\hline Growth Habit & Viny & Viny & Viny & Viny & Viny \\
\hline Stem Pubescence & Densely pubescent & Pubescent & Pubescent & Pubescent & Pubescent \\
\hline Stem Colour & Dark green & Green & Green & Green & Green \\
\hline Stem shape & Angular & Angular & Angular & Angular & Angular \\
\hline Petiole Pubescence & Pubescent & Pubescent & Pubescent & Pubescent & Pubescent \\
\hline Lamina Type & Entire & $\begin{array}{c}\text { Serrated, entire, } \\
\text { multifid }\end{array}$ & Serrated & Serrated, multifid & Serrated, multifid \\
\hline Lamina Colour & Light green & Light green & Light green & Light green & Light green \\
\hline Tendrils Type & Coiled \& branched & Coiled \& branched & Coiled \& branched & Coiled \& branched & Coiled \& branched \\
\hline Flower Colour & White & White & White & White & White \\
\hline Fruit Rind Colour & $\begin{array}{l}\text { Dark green with } \\
\text { white Stripe }\end{array}$ & Light green & Darkish light green & Light green & Darkish light green \\
\hline Fruit Surface & Smooth \& striped & Smooth \& Striped & Smooth \& Striped & Smooth \& Striped & Smooth \& Striped \\
\hline RindThickness & Thin & Thin & Medium thick & Thick & Medium thick \\
\hline Fruit Shape & Elongated, medium & Elongated & Elongated & Elongated, medium & Short, club-shaped \\
\hline
\end{tabular}

Table.2 Analysis of variance (mean squares) for four mutant lines of snake gourd along with control (GB Desi)

\begin{tabular}{|c|c|c|c|c|c|c|c|c|c|c|}
\hline Characters & $\begin{array}{l}\text { Degree of } \\
\text { freedom }\end{array}$ & $\begin{array}{c}\text { Number } \\
\text { of } \\
\text { Primary } \\
\text { branches }\end{array}$ & $\begin{array}{c}\text { Days to } \\
50 \% \\
\text { flowering }\end{array}$ & $\begin{array}{c}\text { Number } \\
\text { of nodes } \\
\text { on main } \\
\text { stem }\end{array}$ & $\begin{array}{c}\text { Sex ratio } \\
\text { (M:F) }\end{array}$ & $\begin{array}{l}\text { Number } \\
\text { of fruits } \\
\text { per plant }\end{array}$ & $\begin{array}{c}\text { Average } \\
\text { fruit } \\
\text { weight (g) }\end{array}$ & $\begin{array}{l}\text { Girth of } \\
\text { fruit }(\mathbf{c m})\end{array}$ & $\begin{array}{l}\text { Length of } \\
\text { fruit }(\mathrm{cm})\end{array}$ & $\begin{array}{c}\text { Fruit } \\
\text { yield per } \\
\text { plant (kg) }\end{array}$ \\
\hline Replication & 4 & 0.033 & 23.998 & 39.039 & 3.616 & 0.513 & 96.345 & 0.579 & 6.620 & 0.121 \\
\hline Treatment & 4 & $15.487 * *$ & $106.39 * *$ & $474.670 * *$ & $20.270 * *$ & $45.294 * *$ & $22891.47 * *$ & $83.249 * *$ & $276.028 * *$ & $0.501 * *$ \\
\hline Error & 16 & 0.056 & 16.248 & 21.628 & 0.566 & 0.271 & 159.25 & 3.053 & 5.101 & 0.027 \\
\hline
\end{tabular}


Table.3 Genetic variability for various quantitative traits of selected mutants of snake gourd and control

\begin{tabular}{|c|c|c|c|c|c|c|c|c|c|}
\hline \multirow[t]{2}{*}{ Characters } & \multirow[t]{2}{*}{ Mean } & \multicolumn{2}{|c|}{ Range } & \multirow{2}{*}{$\begin{array}{l}\text { CV } \\
(\%)\end{array}$} & \multirow{2}{*}{$\begin{array}{r}\text { PCV } \\
(\%)\end{array}$} & \multirow{2}{*}{$\begin{array}{c}\text { GCV } \\
(\%)\end{array}$} & \multirow{2}{*}{$\begin{array}{c}\text { Broad-sense } \\
\text { heritability } \\
(\%)\end{array}$} & \multirow{2}{*}{$\begin{array}{l}\text { Genetic } \\
\text { advance }\end{array}$} & \multirow{2}{*}{$\begin{array}{c}\text { Genetic } \\
\text { advance as } \\
\% \text { of Mean }\end{array}$} \\
\hline & & Min. & Max. & & & & & & \\
\hline $\begin{array}{c}\text { Number of Primary } \\
\text { branches }\end{array}$ & 2.85 & 1.20 & 5.80 & 8.30 & 62.20 & 61.64 & 98.22 & 3.59 & 125.85 \\
\hline Days to $50 \%$ flowering & 61.52 & 55.80 & 68.48 & 6.55 & 9.52 & 6.90 & 52.60 & 6.34 & 10.31 \\
\hline $\begin{array}{c}\text { Number of nodes on main } \\
\text { stem }\end{array}$ & 38.25 & 28.50 & 53.20 & 12.16 & 27.70 & 24.89 & 80.73 & 17.62 & 46.07 \\
\hline Sex ratio(M:F) & 23.64 & 21.98 & 26.56 & 8.16 & 11.52 & 8.13 & 49.85 & 2.80 & 11.83 \\
\hline Number of fruits per plant & 8.60 & 6.80 & 13.94 & 6.05 & 35.41 & 34.89 & 97.08 & 6.09 & 70.81 \\
\hline Average fruit weight (g) & 168.05 & 97.62 & 280.20 & 7.51 & 40.82 & 40.12 & 96.62 & 136.53 & 81.25 \\
\hline Girth of fruit $(\mathrm{cm})$ & 16.15 & 12.77 & 22.42 & 10.82 & 27.06 & 24.80 & 84.01 & 7.56 & 46.83 \\
\hline Length of fruit(cm) & 26.87 & 15.80 & 34.83 & 8.40 & 28.65 & 27.39 & 91.40 & 14.50 & 53.95 \\
\hline Fruit yield per plant (kg) & 1.31 & 1.11 & 1.85 & 12.48 & 26.57 & 23.45 & 77.92 & 0.56 & 42.64 \\
\hline
\end{tabular}

Table.4 Mean performance for nine characters in 4 advanced mutant lines of snake gourd and its control

\begin{tabular}{|c|c|c|c|c|c|c|c|c|}
\hline Characters & $\begin{array}{c}\text { GB Desi } \\
\text { (Control) }\end{array}$ & BCSG 1 & BCSG 2 & BCSG 3 & BCSG 4 & $\begin{array}{l}\text { Grand } \\
\text { Mean }\end{array}$ & $\operatorname{SEm}( \pm)$ & $\begin{array}{l}\text { C.D. } \\
(5 \%)\end{array}$ \\
\hline Days to 50\% flowering & 55.80 & 68.48 & 60.20 & 62.60 & 60.50 & 61.52 & 1.80 & 5.40 \\
\hline Sex ratio $(\mathrm{M}: \mathrm{F})$ & 22.40 & 21.98 & 26.56 & 22.05 & 25.2 & 23.64 & 0.86 & 2.59 \\
\hline Number of fruits per plant & 6.97 & 6.80 & 7.60 & 7.70 & 13.94 & 8.60 & 0.23 & 0.70 \\
\hline Average fruit weight (g) & 280.20 & 165.49 & 147.96 & 148.96 & 97.62 & 168.05 & 5.64 & 16.91 \\
\hline Length of fruit (cm) & 34.83 & 25.37 & 32.49 & 25.88 & 15.80 & 26.87 & 1.01 & 3.03 \\
\hline Fruit yield per plant (kg) & 1.85 & 1.11 & 1.12 & 1.14 & 1.34 & 1.31 & 0.07 & 0.22 \\
\hline
\end{tabular}


The number of fruits per plant ranged from 6.80 to 13.94 with a mean value of 8.60 . BCSG-4 (13.94) significantly increased more number of fruits per plant than the other putative mutant lines and control. Significant differences did exist among BCSG-3 with BCSG-1 and the control (6.80). Similar results in sponge gourd have been reported by Kumar et al., (2002). However, lower number of fruits per plant was reported by Datta (1994) in snake gourd in $\mathbf{M}_{4}$ generation.

Fruit length ranged from 15.80 to $34.83 \mathrm{~cm}$ with a grand mean of $26.87 \mathrm{~cm}$. Among the mutants, maximum fruit length was observed in BCSG-2 $(32.49 \mathrm{~cm})$ and it was significantly different from other mutants, only to be followed by BCSG-3 $(25.88 \mathrm{~cm})$ and BCSG-1 $(25.37 \mathrm{~cm})$. The mutant lines showed decreased value in length of fruit than the parental control line $(34.83 \mathrm{~cm})$. The shortest fruit was obtained in BCSG-4 with a length of $15.80 \mathrm{~cm}$ (Table 4), short fruited snake gourd mutants have been obtained by Sardar et al., (1987). Among the mutants and control, fruit girth ranges from $12.77 \mathrm{~cm}$ to $22.42 \mathrm{~cm}$ with a grand mean of $16.15 \mathrm{~cm}$. The maximum fruit girth was obtained in parental control line $(22.42 \mathrm{~cm})$ than that the other mutants. BCSG-2 $(18.06 \mathrm{~cm})$ noted the maximum fruit girth followed by BCSG-1 (14.35cm) and BCSG-3 $(13.14 \mathrm{~cm})$. Minimum girth of fruit was recorded in BCSG$4(12.77 \mathrm{~cm})$. BCSG-2 recorded significant difference with the others but BCSG-1, BCSG3 and BCSG-4 were found to be statistically at par. However, Datta (1994) reported increased fruit circumference in $\mathrm{M}_{4}$ generation over the parent in snake gourd.

Average fruit weight varied from $97.62 \mathrm{~g}$ (BCSG-4) to $280.20 \mathrm{~g}$ (GB Desi) with a mean of 168.05 g. Fruit weight significantly decreased in case of all the four mutants but the control $(280.20 \mathrm{~g})$. Among them, the maximum fruit weight was recorded in BCSG 1 (165.49 g) followed by BCSG-3 (148.96 g) and BCSG-2 $(147.96 \mathrm{~g})$. BCSG-4 noted the minimum average fruit weight $(97.62 \mathrm{~g})$ and it was significantly different from the others (Table 3 ).
Lower fruit weight in $\mathrm{M}_{4}$ generation of snake gourd has also been also reported by Datta (1994). However, Kumar et al., (2002) reported increased fruit weight in sponge gourd. The range for fruit yield per plant was from 1.46 to $2.58 \mathrm{~kg}$ with a mean value of $1.46 \mathrm{~kg}$. Reduced fruit yield per plant have been recorded in all the four mutants than the control $(2.58 \mathrm{~kg})$. The highest yield per plant was recorded in BCSG-4 $(1.34 \mathrm{~kg})$ followed by BCSG-3 $(1.14 \mathrm{~kg})$ and BCSG-2 (1.12 kg); while, BCSG-1 (1.11 kg) registered the minimum fruit yield per plant (Table 4). Similarly, lower fruit yield was also obtained by Adamu et al., (2004) in tomato and Chakraborty et al., (1998) got higher yield in mung bean treated with gamma radiation.

No putative mutants surpassed the parental genotype, (GB Desi) for fruit yield per plant. An increase in number of fruits per plant was noted in $\mathrm{M}_{4}$ generation of all the selected mutant lines as compared to the parent. The PCV and GCV values corroborated well in case of number of primary branches, average fruit weight, fruit yield per plant, number of fruits per plant and length of fruit coupled with moderate to very high broad sense heritability and genetic advance as per cent of mean indicating that selection based on these traits would be a rewarding one.

It may be concluded from the above result that, BCSG-4 has been found to be the best in terms of fruit yield, number of fruits, sex ratio, fruit length and girth. For confirmation of the stability of the desirable changes, $\mathrm{M}_{5}$ and successive generations need to be raised. Applied mutagenesis by gamma rays caused appreciable variation in snake gourd which may be utilized in further breeding programmes.

\section{References}

Adamu, A. K., Clung, S. S. and Abubakar, S. 2004. Effects of ionizing radiation (gammarays) in tomato (Lycopersicon esculentum L.). Nigeria Journal of Experiments and Applied Biology. 5(2): 185-193.

Ahmed, M. S., Rasul, M. G., Bashar, M. K. and 
Mian, A. S. M. 2000. Variability and heterosis in snake gourd (Trichosanthes anguina L.).Bangladesh Journal of Plant Breeding and Genetics. 13: 27-32.

Allard, R. W. 1960. Principles of plant breeding. J. Wiley and Sons, New York.

Burton, G.W. 1952. Quantitative inheritance in grasses. Proceeding on 6th International Grass Conservation. Pp. $277-283$.

Chahal, G.S. and Gosal, S.S. 2002. Principles and procedures of plant breeding: Biotechnological and conventional approaches. Alpha Science International, Harrow, UK.

Chakarabati, A. A. 1982. Fasicles of Flora of India II. Cucurbitaceae. Botanical Survey of Hawara, WB. Pp. 36.

Chakraborty, R. K., Bhowmik, A., Hossain, T. and Mian, M. A. K. 1998. Induction of mutation in mung bean (Vigna radiata) through gamma-irradiation. Annals of Bangladesh Agriculture. 8: 129-136.

Dalve, P. D., Musmade, A. M., Mane, S. V. and Nimbalkar, R. R. 2009. Response of okra to gamma rays and EMS in M1 generation. Asian Journal of Horticulture. 4(2): 398400.

Datta, S. K. 1994. Induction and analysis of short thick fruit mutant in Trichosanthes anguina L. Indian Journal of Genetics and Plant breeding. 54(1): 13-17.

Gomez, K.A., and Gomez, A.A. 1983. Statistical procedure for agricultural research 2nd ed., John Wiley and Sons, New York. Pp. 375427.

Iwo, G. A., Amadi, C. O., Eleazu, C. O., and Ukpabi, J. U. 2013. Induced Mutagenesis on Ginger for Improved Yield Components and Oleoresin Content. Canadian Journal of Plant Breeding. 1(3): 90 -96.

Johnson, H.W., Robinson, H.F. and Comstock, R.E. 1955. Estimates of genetic and environmental variability in soybean. Agronomy Journal. 47(7): 314-318.

Kumar S., Kumar S., Singh, B., Virendra Jatav. A. L. and Kumar S. 2002. Influence of gamma radiation of seed on growth, sex expression and yield in sponge gourd (Luffa cylindrica L.). Plant archives. 2(2): 25-28.

Mba, C. and Shu, Q.Y. 2012. Gamma Irradiation. In Plant Mutation Breeding and Biotechnology; Shu, Q., Forster, B.P., Nakagawa, H., Eds.; CABI: Oxfordshire, UK. Pp. 91-98.

Mikaelsen, K. 1968. Effects of first neutrons on seedling growth and metabolism in barely. Neutron radiation of seeds II. Tech. Rep. Ser.No.92 IAEA, Vienna. Pp: 63-70.

Nath, R. and Madan, S. P. S. 1986. A study of the effects of low doses of gamma irradiation on sex expression, fruit set and yield in Cucumis sativus L. Punjab Vegetable Grower. 21:25-28.

Sardar, A. K. and Mukherjee, K. K. 1987. Analysis of two short-fruit mutants of Trichosanthes anguina L. Indian Journal of Genetics and Plant breeding. 47(3): 257260.

Sidhya, P. and Pandit, M. K. 2015. Mutagenic effectiveness and efficiency of gamma rays in snake gourd (Trichosanthes anguina L.). Journal of Applied and Natural Science. 7(2): $649-651$.

Tester, M. and Langridge, P. 2010. Breeding technologies to increase crop production in a changing world. Science. 327: 818-822.

Wu, T., T. Kamiya, H. Yumoto, N. Sotta, Y. Katsushi, S. Shigenobu, Y. Matsubayashi and T. Fujiwara. 2015. An Arabidopsis thaliana copper-sensitive mutant suggests a role of phytosulfokine in ethylene production. Journal of Experimental Botany. 66(13): 3657-3667.

\section{How to cite this article:}

Santanu Layek, M.K. Pandit, Sanket Kumar, Arindam Das and Anamika Upadhyay. 2019. Qualitative and Quantitative Characterization of Snake Gourd (Trichosanthes anguina L.) Mutant Lines. Int.J.Curr.Microbiol.App.Sci. 8(08): 1797-1803. doi: https://doi.org/10.20546/ijcmas.2019.808.212 